Int. J. Dev. Biol. 59: 159-170 (2015)

doi: $10.1387 / \mathrm{ijdb} .150223 \mathrm{sg}$

\title{
The significance of Hox gene collinearity
}

\author{
STEPHEN J. GAUNT* \\ Department of Zoology, University of Cambridge, Cambridge, UK
}

\begin{abstract}
Arthropods and vertebrates inherited their Hox clusters from an ancestral cluster of at least six genes already present in their last common ancestor, Urbilateria. Clustering and a common transcriptional direction are both likely features of the way that the gene complex first arose in a process of tandem gene duplication. Spatial collinearity (correspondence between ordering of Hox genes along the chromosome and their expression patterns along the head-tail axis) has been conserved in many animal groups and is likely to have been already present in Urbilateria. It is not known why the Hox cluster evolved with spatial collinearity. Four models are discussed. These vary in the significance they place upon Hox chromatin structure, and also on whether they propose that collinearity is primarily concerned with establishment or maintenance of Hox expression. Published proposals to explain spatial collinearity, which invoke enhancer sharing, chromatin closing or chromatin opening, are either problematic or can offer only partial explanations. In an alternative proposal it is suggested here that spatial collinearity evolved principally to maximise physical segregation, and thereby minimise incidence of boundaries, between active and inactive genes within the Hox cluster. This is to minimise erroneous transfer of transcriptional activity, or inactivity, between adjacent Hox genes.
\end{abstract}

KEY WORDS: evolution, embryo, homology, chromatin, polycomb

\section{Discoveries in collinearity}

From genetic mapping studies upon homeotic mutations in the bithorax complex (BX-C) of Drosophila melanogaster, Lewis described correspondence between homeotic gene locations along the chromosome and sites of their mutational effects upon pattern formation along the head-tail axis (Lewis, 1978). He proposed a model in which the genes, now known as Hox genes, are expressed (i) in a series of partially overlapping domains along the axis (Fig. 1A, left), and (ii) with their anterior limits of expression corresponding with gene position along the chromosome (Fig.1A, right). Successive regions along the body then express a different combination of homeotic genes from the complex, and Lewis considered that it is this combination that instructs each region on how it must develop. In his paper (Lewis, 1978), the regions of distinct homeotic gene activity were segments, though we now understand that they are parasegments, offset from segments by a half-segment distance (Martinez-Arias and Lawrence, 1985). In addition, we now know that many of Lewis's homeotic genes are actually regulatory regions, and that there are only three protein coding homeotic genes in BX-C: Ubx, abdA and $A b d B$ (SanchezHerrero et al., 1985) (Fig. 2). While the BX-C regulates develop- ment of Drosophila posterior to the mid thorax, the antennapedia complex (ANT-C) of homeotic genes regulates the anterior parts (Kaufman et al., 1980). ANT-C and BX-C both lie on chromosome 3 but are separated by $10 \mathrm{Mb}$ of DNA (Fig 2).

Following the arrival of molecular biology and in situ hybridization techniques, it was shown that homeotic genes of the BX-C and ANT-C are indeed expressed in overlapping regions along the Drosophila body axis, broadly consistent with Lewis's predictions (Harding et al., 1985). Even the regulatory regions of the BX-C are transcribed, and their transcript positions along the axis conform to Lewis's model (Sanchez-Herrero and Akam, 1989). Within the domains of Fig. 1A, left, expression of a Hox gene may, in practice, be suppressed within individual tissues or segments, and this is often due to the inhibitory actions of co-expressed, more $5^{\prime}$-located Hox genes (Struhl and White, 1985). It is therefore more accurate to view the domains of Fig. 1 A as regions over which the Hox genes are enabled to be active ('open for business') rather than neces-

Abbreviations used in this paper: BX-C, bithorax complex; ANT-C, antennapedia complex; pc, polycomb; Trx, Trithorax; PRE, polycomb response element; RA, retinoic acid; ES cells, embryo stem cells; FGF, fibroblast growth factor; Gdf1 1, growth and differentiation factor 11 .

\footnotetext{
*Address correspondence to: Stephen J. Gaunt. Department of Zoology, University of Cambridge, Downing Street, Cambridge, CB2 3EJ, U.K. Tel: +44-1223-768917. Fax: +44-1223-336676. E-mail: sg397@cam.ac.uk
}

Accepted: 16 July 2015

ISSN: Online 1696-3547, Print 0214-6282 
sarily must be active (Akam et al., 1988, Maeda and Karch, 2015).

Essential features of Lewis's model were also found to apply to vertebrate Hox genes. Thus, in situ hybridization studies showed that Hox genes of mice are similarly expressed in partially overlapping domains along the head-tail axis, and the location of genes along the chromosome corresponds with the positions of their anterior expression limits along the embryo (Gaunt et al., 1988). It was then realized that the two homeotic gene complexes of Drosophila are, together, homologous with each of the four Hox clusters in mammals, showing that both animal types had inherited them from a single cluster of at least six Hox genes present in their last common ancestor (Fig. 2). This homology was described from analysis of human Hox genes (Boncinelli et al., 1988), and then from mouse (Duboule and Dolle, 1989, Graham et al., 1989). The last common ancestor of arthropods and vertebrates has been named 'Urbilateria' (De Robertis, 2008). The four homologous Hox clusters in mammals themselves arose following two rounds of duplication from the single cluster present in basal chordates (Garcia-Fernandez and Holland, 1994). Correspondence between Hox gene chromosomal location and expression was referred to as the collinearity rule (Lewis, 1985), but is now often called the 'structural collinearity' (Izpisua-Belmonte et al., 1991) or 'spatial collinearity' (Duboule, 2007) rule.

It seems likely that Drosophila and vertebrates inherited from Urbilateria not only the ordering of their Hox genes (Fig. 2) but also spatial collinearity in the expression of their Hox genes. Urbilateria may therefore have expressed its Hox genes in accordance with Fig. 1A. The alternative view is that full collinearity in expression arose later, and independently, in arthropod and vertebrate lineages. This would require the unlikely possibility that Hox genes were able to undergo multiple changes in their acquisition of new expression boundaries and functions. The Drosophila Hox cluster and its ex-

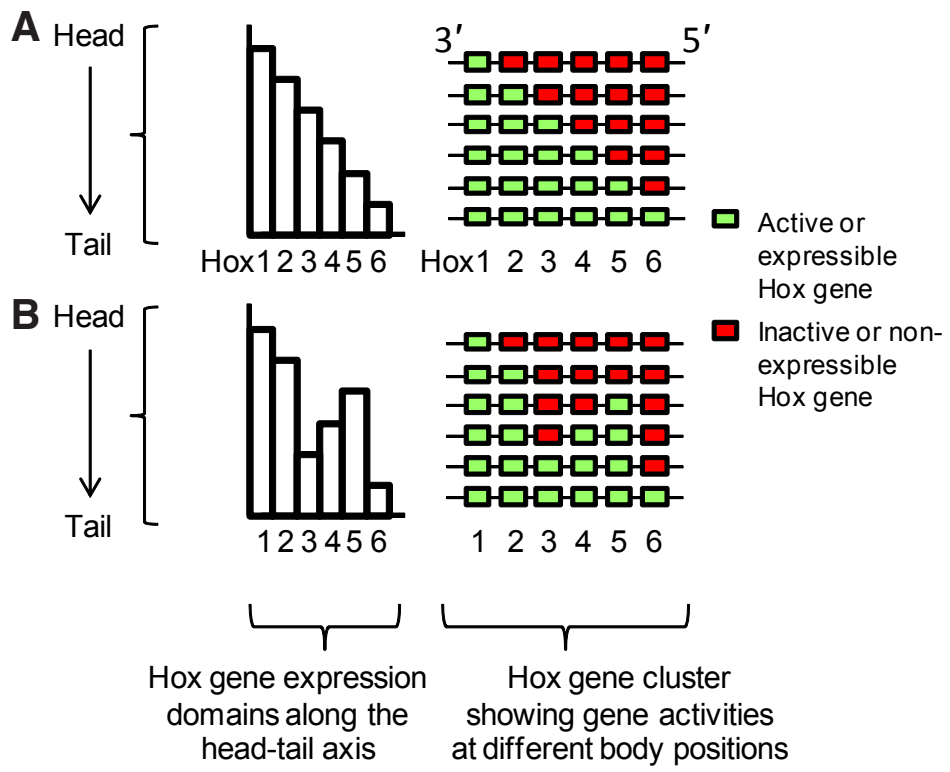

Fig 1. Representation of Lewis's model. (A) Lewis proposed that homeotic genes of the bithorax complex are normally expressed in a series of partially overlapping domains along the axis (left) with their anterior limits of expression corresponding with gene position along the chromosome (right). (B) Violations to Lewis's model, postulated here for Hox3 and Hox5. 5' to 3' indicates directions of transcription. pression conform only in part with Fig. 1A. Thus, ANT-C includes Hox-derived genes which show non-Hox expression patterns and functions, for example fushi tarazu and bicoid. Furthermore, the single ancestral cluster has broken up in Drosophila, with position of the breaks varying between different Drosophila species (Negre and Ruiz, 2007). Spatial collinearity as it persists in Drosophila may therefore be more a vestige of the ancestral condition rather than an essential conserved feature of Hox gene regulation. Vertebrate clusters, in contrast, remain unbroken, do not include non-Hox genes, and conform more closely to Fig. 1A. Spatial collinearity has more recently been found in annelids (Frobius et al., 2008), non-dipteran arthropods (Barnett and Thomas, 2013, Hughes and Kaufman, 2002) and, with some notable exceptions, cephalochordates (Pascual-Anaya et al., 2012). These studies also show partially overlapping patterns of Hox gene expression, broadly consistent with Lewis's model (Fig. 1A).

Ageneral finding in both Drosophila and mouse Hox clusters is that there is a functional hierarchy, with each Hox gene tending to be dominant in its effect relative to its more anteriorly expressed neighbours (Duboule and Morata, 1994, Struhl and White, 1985). This may have evolved and been conserved as the most effective way for a body region to identify its unique positional instruction within the overlapping domains of Hox expression.

The location of mouse Hox genes along the chromosome also corresponds with time of their initial activation in the embryo, and this is called 'temporal collinearity' (Izpisua-Belmonte et al., 1991). While temporal collinearity is not found in Drosophila, it has been found in some annelids (Frobius et al., 2008). Some authors suggest that Urbilateria also possessed temporal collinearity (Ferrier and Holland, 2002), although others view this as a condition probably derived later from spatial collinearity (Duboule, 2007).

\section{Collinear Hox clusters formed by tandem duplication}

The Hox cluster is thought to have arisen by tandem duplications from a single proto-Hox gene. It is most likely that this, and subsequent duplications, occurred due to unequal crossing over between homologous chromosomes at meiosis (Gehring et al., 2009, Lewis, 1998). A feature of each such duplication is that two similar DNA fragments come to lie adjacently and in the same orientation along the same chromosome. This mechanism for generating the original Hox cluster may explain why all vertebrate Hox genes lie in the same transcriptional orientation (Fig. 2). Drosophila Hox genes also lie in this orientation, with the exception of Deformed.

Following a duplication event, it is suggested that one of an identical pair of Hox genes must maintain its function for maintenance of normal development while the other is free to acquire a new pattern of expression and function (Lewis, 1998). Other authors argue that a redundant gene would suffer deleterious mutations long before an advantageous mutation occurred. They propose instead that divergence of the two alleles takes place before the gene duplication event, and that duplication then occurs in heterozygotes bearing functionally distinct alleles (Tarailo-Graovac and Chen, 2013). These alleles may already have acquired slight differences in their functions and/ or expression patterns. After duplication, the two gene copies, now on the same chromosome, may evolve further to encode proteins with more distinct functions and anterior boundaries 
of expression. Gene duplication and modification therefore allow the development of increased anatomical complexity along the head-tail axis. Repeated cycles of gene duplication and mutation permitted ever-increasing complexity, and gave rise to the cluster of at least six different Hox genes in Urbilateria (Boncinelli et al., 1988, Duboule and Dolle, 1989, Graham et al., 1989).

In practice, new expression domains evolved with strict adherence to the collinearity rule. For example, consider that gene 5 in Fig. 1 has arisen by duplication from gene 4 . To maintain collinearity its acquired anterior boundary of expression must lie somewhere between the anterior boundaries of genes 4 and 6 (Fig. 1A). We must assume that if its acquired boundary lies outside this, as for example in Fig. 1B, then this could lead to errors in Hox gene expression, developmental abnormality, and selective disadvantage.

The question is why did Hox genes evolve with spatial collinearity? Spatial collinearity must have some functional importance in the way that Hox gene expression is established, maintained, or interpreted to generate the overt anatomy of an animal. If it were not important it would not have been selected for, and it would not have been retained over evolutionary time. When conservation of the collinearity rule was first discovered, over twenty five years ago, many of us assumed that it would soon lead to a major insight into the way that embryos developed. However, the significance of collinearity still remains a matter of debate.

\section{Additional features of Hox gene function that may be relevant to the need for spatial collinearity}

Various aspects of Hox gene expression have been considered as relevant to the need to maintain collinearity. These are now described.

\section{The Polycomb/Trithorax system for stabilization of Hox inactivity/activity}

As first found in Drosophila, Hox genes originally activated within an early embryonic cell bind Trithorax-group (Trx) proteins to become stably expressible (ON in Fig. 3); Hox genes not activated bind Polycomb-group (Pc) proteins to become stably repressed (OFF in Fig. 3) (Sha and Boyer, 2009). Trx-bound expressible chromatin is also marked by a loose structure and trimethylation of lysine 4 on histone 3 (H3K4me3), whereas Pc-bound repressed chromatin is marked by a compact structure and trimethylation of lysine 27 on histone

Fig 2. Homologous Hox clusters of Drosophila, mouse, and their last common ancestor, Urbilateria. The homology relationships are as commonly presented elsewhere (GarciaFernandez and Holland, 1994). The Urbilateria cluster probably had more than the six Hox genes shown here (Balavoine et al., 2002). For example, both Hox2 and Hox3 of vertebrates were likely represented in Urbilateria: Hox3 has given rise to bicoid and zerknüllt in Drosophila but remains as a Hox gene in some other nonarthropodinvertebrates. Arrows show directions of transcription (presumed for Urbilateria).
3 (H3K27me3) (Bantignies and Cavalli, 2011, Chambeyron and Bickmore, 2004, Sha and Boyer, 2009). Once set up, these chromatin states are normally maintained through cell division (Steffen and Ringrose, 2014), providing a clonally heritable memory of Hox gene activation patterns.

In mouse, embryo stem (ES) cells are the commonly studied model for the embryo prior to Hox gene expression. These have Hox clusters that bind both Pc and Trx (Fig. 3). They are in a socalled 'bivalent' state (Bernstein et al., 2006). This means that they do not express Hox genes, but are fully sensitive to being activated by transcription factors (Schuettengruber and Cavalli, 2009). Bivalent chromatin is considered to be 'poised' for either expression or repression according to the region-specific signals that cells encounter along the head-tail axis of the embryo. Currently there is no evidence for a structurally similar bivalent chromatin in Drosophila (Schuettengruber et al., 2009), although there may be in plants (Avramova, 2009).

Boundary elements, firstidentified in Drosophila, act as insulators to prevent spread of Pc or Trx components between repressed and active chromatin domains (Barges etal., 2000). Boundary elements in vertebrate Hox clusters are less well characterized. One element upstream of Hoxd13 is functional in Drosophila (Vasanthi et al., 2010), though it may not function in this way in mouse. However, mouse CCCTC-binding factor (CTCF) is able to establish a boundary in the central region of the Hoxa cluster, partitioning it into two separate chromatin domains, and disruption of this CTCF binding results in ectopic Hox gene expression (Narendra et al., 2015).

The $\mathrm{Pc} / \mathrm{Tr}$ system is ancient, being found to varying extent in most metazoa, including plants (Avramova, 2009, Hennig and Derkacheva, 2009, Schuettengruber et al., 2007), and so it is expected that it would have been present in Urbilateria. It is a reasonable hypothesis that Urbilateria used the $\mathrm{Pc} / \mathrm{Trx}$ mechanism for stabilization of its Hox gene expression patterns, and that this was inherited as a homologous mechanism in Drosophila and mouse.

Repressed Pc-bound Hox genes tend to coalesce together into expression-silent 'polycomb bodies' or 'hubs', which form discreet

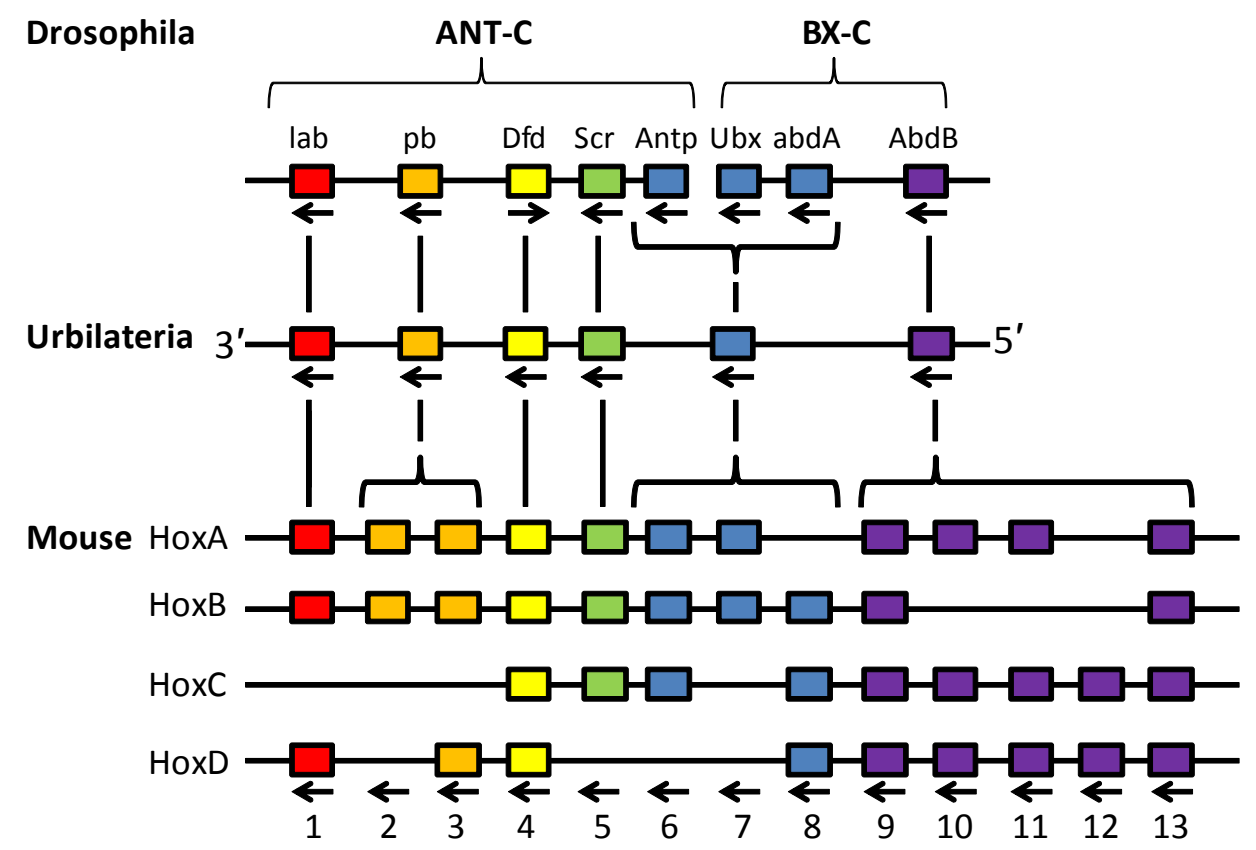




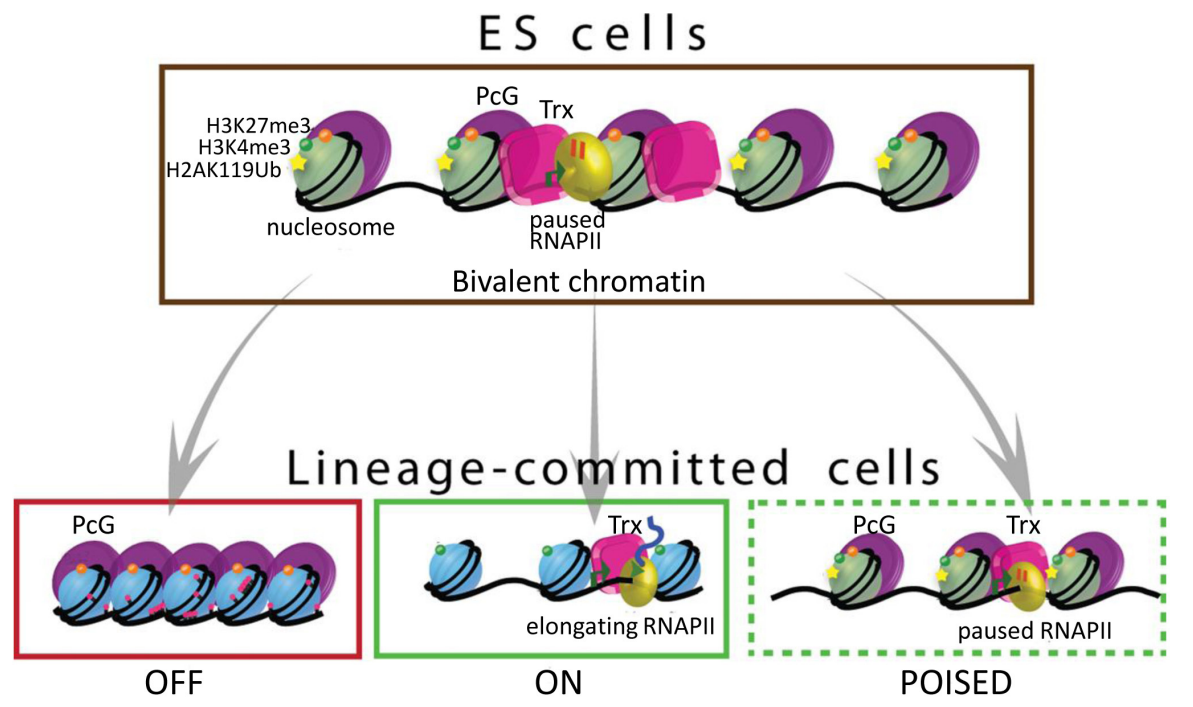

Fig 3. The Pc/Trx system for stabilization of Hox activity patterns. Hox genes initially activated in the embryo are rendered stably ON by binding Trithorax (TrX) components, acquiring H3K4me3 marks, and adopting a loose structure. Hox genes not initially activated are rendered stably OFF by binding Polycomb group (PCG) components, acquiring H3K27me3 marks, and adopting a compact structure. In mouse, uncommitted cells prior to Hox expression, as evidenced from studies upon embryo stem (ES) cells, are in a bivalent state where they are considered to be poised for transition of their Hox genes to either the ON or OFF states. The RNA polymerase II (RNAPII) in these cells is paused, possibly requiring mono-ubiquitination of lysine 119 on histone H2A (H2AK119Ub). From Sha and Boyer, 2009. structures within the cell nucleus (Casa and Gabellini, 2012, Lanzuolo et al., 2007). Similarly, the Trx-bound genes, when active, occupy discreet regions called 'transcription factories' (Casa \& Gabellini, 2012; Lanzuolo et al., 2007). It is suggested that it is only within Pc hubs and transcription factories that there is sufficient concentration of regulatory proteins (Pc- or Trx-complex components and transcription factors) to ensure efficient Hox gene repression or activation (Maeda and Karch, 2009, Sutherland and Bickmore, 2009).

\section{Hox gene expression occurs in two stages: establishment and maintenance}

Hox expression boundaries become established while the embryo is tiny in size, yet Hox activity remains important to regulate development at both early and late stages. Hox expression probably establishes early because it depends upon gradients of signalling molecules (morphogens) that can only develop across small groups of cells. The cell groups soon out-grow the range of these signals and an alternative mechanism must take over to stabilize Hox gene activity in a clonal manner. This maintenance mechanism depends, at least in part, upon the Pc/Trx system.

The substantial growth of a Hox expression domain during mouse embryogenesis is illustrated in Fig. 4. This shows Hoxa7/ lac $Z$ transgene expression over the period of embryonic development from 7.8 days to 14.5 days. Region-specific patterns of Hox expression continue to be maintained in some tissues even into adult life. For example, skin fibroblasts and bone marrow mesenchymal stem cells continue to show evidence of the head-tail Hox activity that their progenitor cells first acquired in the early embryo, even after a period in culture (Wang et al., 2009). Clonal memory of Hox gene activity is also crucially important in Drosophila. Patterns of Hox gene activity established in the embryo must be carried in the imaginal discs throughout larval development, later to be read-out during metamorphosis for specification of the adult fly anatomy.

Distinct establishment and maintenance (memory) stages of Hox gene activity are understood most clearly in Drosophila. They represent, respectively, Pc/Trx-independent and Pc/Trx-dependent stages. Pc-deficient Drosophila embryos establish normal Hox expression boundaries at the cellular blastoderm stage but then these spread forward, anterior to their normal positions. $A b d B$ expression spreads forward over much of the embryo causing transformation of most segments towards the phenotype of the eighth abdominal segment (Lewis, 1978, Paro, 1990). Similarly, Drosophila Hox/lacZ transgenes, randomly integrated, mimic endogenous Hox gene expression initially, but they maintain this only if they incorporate a polycomb response element (PRE) to permit Pc binding (Busturia et al., 2001, Maeda and Karch, 2006, Maeda and Karch, 2009, Schwartz and Pirrotta, 2007).

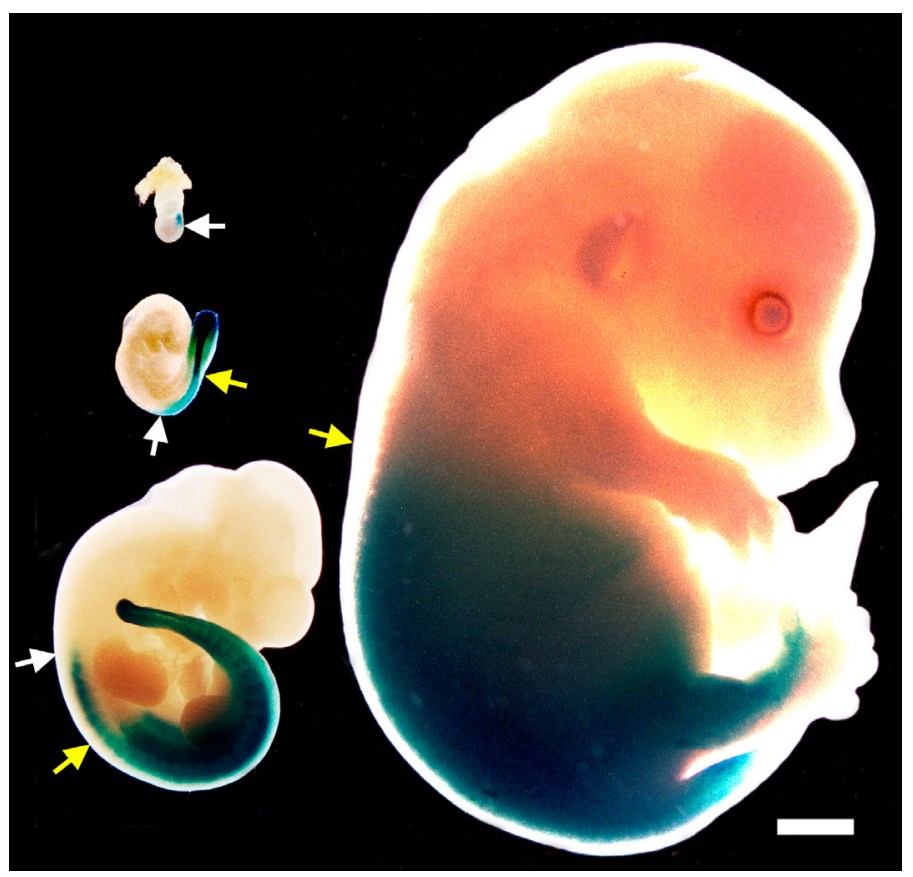

Fig 4. Hox expression domains undergo considerable growth during embryogenesis. Expression of a Hoxa7/lacZ reporter transgene, which mimics endogenous Hoxa7 expression, is shown stained blue at 7.8, 9, 10, and 14.5 days of mouse embryogenesis. The 7.8 day embryo includes extraembryonic tissues. Arrows indicate anterior boundaries of lacZ expression. At later stages, separate neurectoderm (white arrow) and mesoderm (yellow) boundaries are marked. The 14.5 day neural boundary is obscured by tissue opacity. All embryos are shown at the same magnification. Bar, $1 \mathrm{~mm}$. 
Similar mechanisms are reported in mice. Mice knocked out for both Mel18 and Bmi1, two genes which encode functional homologues from the Pc-complex of proteins, display normal Hoxb6 expression in 8.5 day embryos but an anterior shift of Hoxb6 expression by 9.5 days (Akasaka et al., 2001). Mice knocked out for MLL, the homologue of Drosophila Trx, display normal Hoxa7 expression in embryos before 9 days but most of this expression is prematurely lost after 9 days (Yu et al., 1998). In both cases, the authors conclude that, as in Drosophila, Pc- and Trx-complexes are required for memory but not establishment of Hox expression domains. However, the potential role of polycomb in memory of mouse Hox/lacZ transgene expression is not yet clear.

\section{Embryonic development from posterior growth zones}

In mouse and chick, the embryonic axis extends by addition of new cells from posterior growth zones located in the node/ primitive streak, and then later in the tailbud (Sweetman et al., 2008, Wilson et al., 2009) (Fig. 5). Anterior regions of the body are therefore laid down earlier than more posterior regions. More anterior growth zones give rise to axial structures (notochord and neural tube), while more posterior growth zones give rise to progressively more lateral embryonic structures (Sweetman et al., 2008). Within each growth zone and its emergent cells the Hox genes are progressively activated, anterior to posterior, $3^{\prime}$ to $5^{\prime}$, along the cluster to establish the overlapping pattern of Hox gene expression (Izpisua-Belmonte et al., 1991). Due to spatial collinearity (Fig. 1A) it follows necessarily that Hox genes become activated progressively, $3^{\prime}$ to $5^{\prime}$, along the clusters. This is the phenomenon of temporal collinearity. Temporal collinearity itself does not necessarily have any function. Spatial collinearity might be the important feature, and temporal collinearity may simply be a consequence of this.

\section{Significance of collinearity model 1: enhancer sharing}

Krumlauf and colleagues proposed that cluster organization is maintained because each Hox gene must remain associated with its enhancer elements, and these may be distributed widely outside the immediate vicinity of the gene (Graham et al., 1989). In support of this, they later identified several Hoxb intergenic enhancers each of which activates similar patterns of expression from both of its two neighbouring Hox genes. The CR3 enhancer located between Hoxb4 and Hoxb3 activates neural expression of both genes up to the level of rhombomere 6/7 (Gould et al., 1997). A separate kreisler-dependent enhancer activates Hoxb3in rhombomere 5, and hence sets

Fig 5. Development of the mouse embryo proceeds with temporal collinearity in Hox gene activation within cells of posteriorly-located growth zones. Left, Hox genes; right, Hox gene expression. Three stages of development are shown. The figure is simplified in that presomitic/somitic mesoderm originates from more than one growth zone. Also, each Hox gene normally continues its expression posteriorly, to overlap with that of its $5^{\prime}$ neighbours. Post, posterior; Ant, anterior; ps, primitive streak; $n$, node; psm, presomitic mesoderm; $s$, somite; nt, neutral tube. up the distinct anterior expression boundaries of Hoxb4 and Hoxb3 (Kwan et al., 2001). Further examples of shared enhancers are a somitic enhancer located between Hoxb5 and Hoxb4 (Sharpe et al., 1998), a neural enhancer between Hoxb6 and Hoxb5 (Sharpe et al., 1998), and a neural/mesoderm enhancer between Hoxd11 and Hoxd10 (Zakany et al., 1997).

These shared, local enhancers can explain a need for proximity between certain pairs of mouse Hox genes, but it is not yet obvious how they can explain spatial collinearity along the entire cluster. For example, Hoxb4 must clearly maintain proximity to Hoxb3 (Gould et al., 1997), but why must Hoxb4 have its expression boundary posterior to Hoxb3, and not vice versa? Krumlauf and colleagues concluded that enhancer sharing could explain part, though not the whole, of the need for spatial collinearity (Sharpe et al., 1998).

An important conclusion from these experiments is that mouse Hox genes are not rigidly prevented from enhancer sharing. Some prevention does occur since, for example, the Hoxb3 rhombomere 5 element does not act upon Hoxb4. This prevention could be due to distance along the chromosome, or else to selective boundary elements (Sharpe et al., 1998). Boundary elements for prevention of enhancer sharing are more generally recognized in Drosophila (Barges et al., 2000, Mihaly et al., 1997) and the same elements may also act as barriers to spread of $\mathrm{Pc} / \mathrm{Trx}$ components (Barges et al., 2000). Even in Drosophila, the iab-5regulatory region apparently cis-regulates both $a b d A$ and $A b d B$ genes (Celniker et al., 1990).

Enhancer sharing may potentially have been important in establishment of the ancestral Hox cluster. Suppose, for example, that Hox5 has newly formed by duplication from Hox4 (Fig. 1A). Hox5 might share an enhancer with Hox4 to activate its domain of expression, and Hox4 may also have acquired a new enhancer to extend its expression anteriorly. If enhancer sharing was an important feature of the Hox cluster in Urbilateria then we might expect to find that it is conserved to some extent in invertebrates today.

Detrimental effects of enhancer sharing could potentially have played a part in ancestral development of spatial collinearity. Suppose a new Hox gene arose in the ancestral cluster with enhancer activity driving its expression anterior to that of its $3^{\prime}$ neighbour (such as Hox5 in Fig. 1B). The new enhancer may then also drive

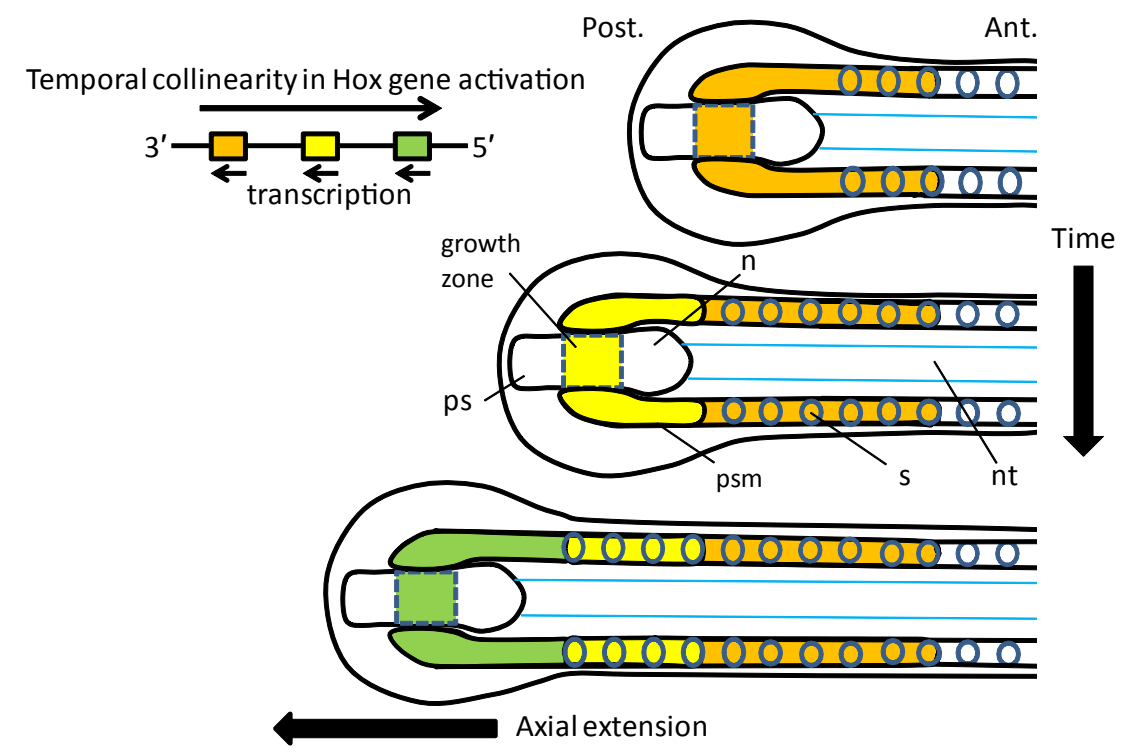


forward the expression of this neighbour, producing homeotic transformation. There would therefore be selective pressure for the new enhancer to position expression of the new gene posterior to that of its $3^{\prime}$ neighbour, as in spatial collinearity. However, the explanation remains incomplete since it is not clear what would prevent the new enhancer from driving forward expression of the more $5^{\prime}$ gene. The detrimental effects of enhancer sharing may better explain why Hox genes are conserved in the same orientation (Fig. 2). Inversions can bring Hox genes under the influence of their neighbours' enhancers, and thereby cause homeotic transformations and selective disadvantage (Schneuwly et al., 1987).

More recently, Duboule and colleagues have identified global enhancer elements at long distances both upstream and downstream of the mouse Hoxd complex (Andrey et al., 2013, Spitz et al., 2003). The Hoxd cluster without these global elements is able to express its Hox genes with normal boundaries along the head-tail axis, but not in the limbs (Spitz et al., 2001). It appears that global elements have permitted the vertebrate Hox cluster to regulate Hox expression patterns along axes that are phylogenetically more recent, such as in limbs. Regulation by these elements may have led to compaction of Hox gene clusters in vertebrates (Duboule, 2007, Spitz et al., 2005), and may be important in conservation of their spatial collinearity (Monteiro and Ferrier, 2006). However, it seems unlikely that the Urbilateria Hox cluster utilized global control elements; otherwise we might expect that some of its invertebrate descendants would show the same phenomenon of cluster compaction now found in vertebrates. Global control from outside the Hox cluster is therefore likely to be a derived condition in vertebrates, evolved to re-utilize the Hox genes to provide developmental patterning along new body axes, such as in limbs (Duboule, 2007).

Transcriptional read-through between adjacent Hox genes provides another example of enhancer sharing. This is reported in crustaceans, but posttranscriptionalmechanisms prevent the potentially adverse effects of shared expression domains (Shiga et al., 2006). It has been suggested that human Hox genes Hoxc6, Hoxc5 and Hoxc4 may be transcribed in placenta as a single primary transcript, and that this may account for how the same 5 ' non-coding exon can become spliced on to both Hoxc6and Hoxc4 mature mRNAs (Simeone et al., 1988). Transcription is also found to cross between some other mammalian Hox genes (Mainguy et al., 2007) but the function is unknown.

\section{Significance of collinearity model 2: gene segregation}

It is suggested here that spatial collinearity may have evolved principally to maximise physical segregation, and thereby minimise incidence of boundaries, between active and inactive Hox genes within the Hox cluster. The discreet blocks of active and inactive Hox genes predicted in Lewis's model (Fig. 1A, right), and recently evidenced both by patterns of H3K27me3 chromatin marks (Fig. 6) (Bowman etal., 2014, Narendra et al., 2015, Soshnikova and Duboule, 2009) and by accompanying three dimensional folding of the Hox cluster into distinct active and inactive domains (Noordermeer et al., 2011), indicate that there is only one principal transition boundary between these states. Fig. 1B shows two hypothetical situations in which regulatory mutations have caused Hox genes 3 and 5 to express outside the collinearity rule. This results in two new situations at certain locations along the body. First, active and inactive genes are no longer fully segregated: Hox3 becomes an inactive gene in a block of active genes; and Hox5 becomes an active gene in a block of inactive genes. Second, in each of these scenarios there will now be three transition boundaries between expressing and non-expressing genes (Fig. 1B).

Increase in the number of transition boundaries could be significant if there is risk of accidental leakage from expressing to non-expressing states across the boundaries. The embryo in Fig. $1 \mathrm{~B}$ would then carry a greater risk of miss-expression than the embryo in Fig. 1A, and such an individual would be at a selective

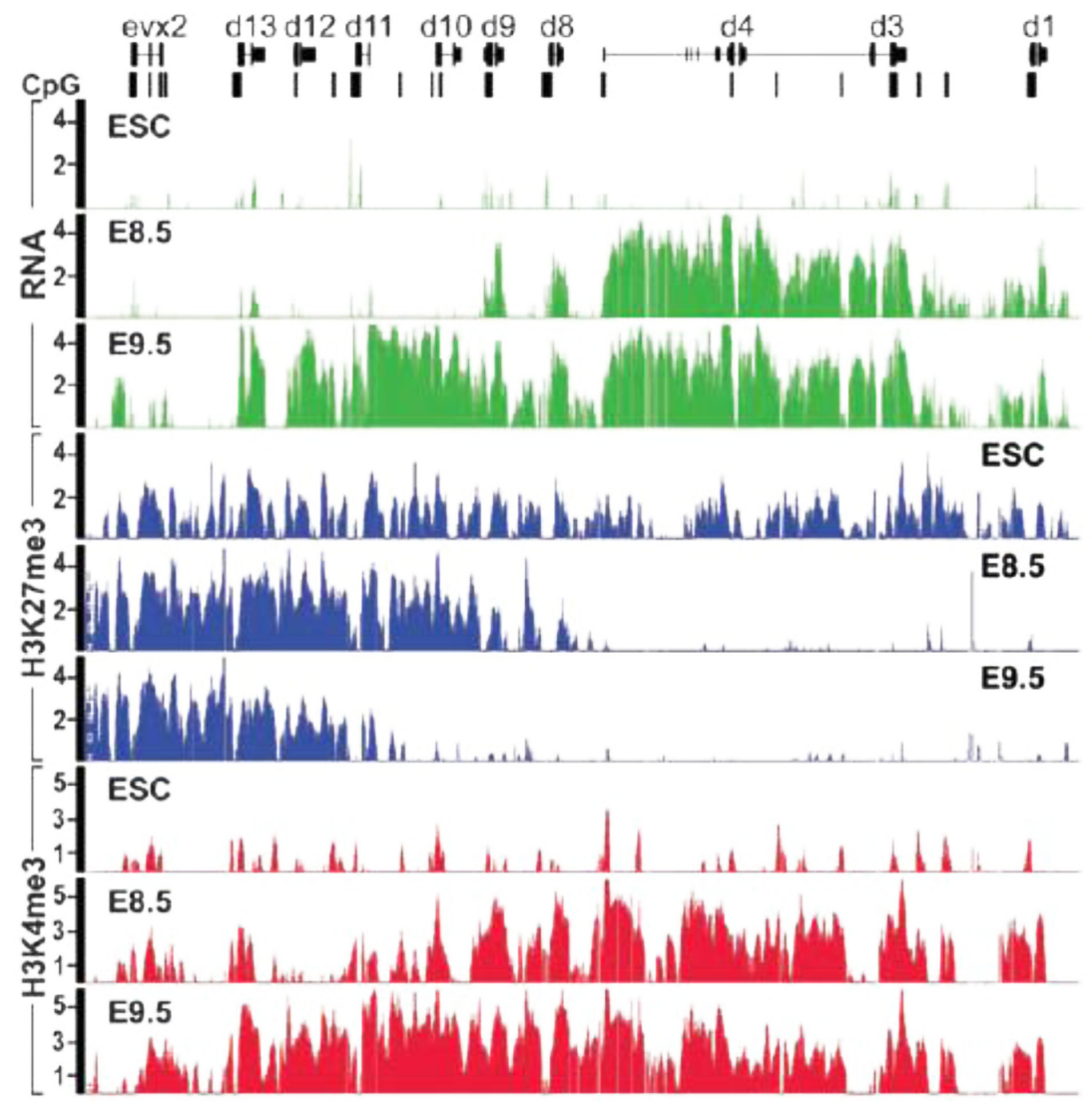

Fig 6. Chromatin marks and Hox expression in tailbuds from 8.5 day and 9.5 day mouse embryos. Over this period of development more posterior tissues arise within the tailbud and, correspondingly, more posterior Hox genes (Hoxd8 to d13) become expressed. There is accompanying loss of H3K27me3 and gain of H3K4me3 marks. H3K27me3 marks, in particular, suggest evidence of a single boundary between active and inactive Hox genes, and the position of this boundary in the cluster has shifted in the more posterior (older) tailbud. Embryo stem cells (ESC) are used to represent an earlier Hox-inactive stage. They show ubiquitous presence of both $\mathrm{H} 3 \mathrm{~K} 27 \mathrm{me} 3$ and $\mathrm{H} 3 \mathrm{~K} 4 \mathrm{me} 3$ marks, characteristic of bivalent chromatin, but at levels less than those reached after Hox gene expression. ESC, embryo stem cells. From Soshnikova and Duboule, 2009. Reprinted with permission from AAAS. 
disadvantage. The main risk of leakage is unclear. One possibility is breakdown of boundary elements, permitting enhancer sharing or erroneous exchange of $\mathrm{Pc} / \mathrm{Trx}$ components between adjacent $\mathrm{Hox}$ genes. Although boundary elements appear robust in Drosophila it is possible that they were less so ancestrally, and this could have contributed to the initial setting up of the Hox cluster with spatial collinearity. The risk here could operate either at the level of establishment or memory of Hox gene expression.

Alternatively, the main handicap might lie in the loss of segregation between active and inactive genes. For example, Hox5 in Fig. 1B may be hampered in its entry to a transcription factory because its flanking genes enter a Pc hub. Similarly, Hox3 might be inhibited from entering a polycomb hub because its flanking genes occupy a transcription factory. Little is known about the topographic constraints on these events. The effect upon Hox expression may only be quantitative but this alone might be sufficient to promote homeotic mutation and selective disadvantage. The proposal here is therefore that Hox genes maintain their levels of expression more reliably when active and inactive Hox genes are grouped separately within either fully active or fully repressed chromatin domains (Fig. 1A, 6). This effect would likely operate at the level of cellular memory, rather than establishment, of Hox expression.

These proposed interferences between Hox genes could, in an alternative scenario, be overcome by a strategy of dispersal from the ancestral cluster. Hox clusters in several animal groups have indeed fragmented. Tunicate Hox genes, for example, are dispersed, yet their expression retains the ancestral pattern of spatial collinearity (Seo et al., 2004). This has been named 'trans-collinearity', as opposed to 'cis-collinearity' where Hox genes remain together as in mouse or, to a large extent, Drosophila (Duboule, 2007). The tunicate finding does, however, raise the important question of why Hox genes have remained together in any species. Although Pc binding can occur on an isolated gene (Simon and Kingston, 2013), clustering may be selectively advantageous in offering high and stable concentrations of regulatory proteins within Pc hubs and transcription factories (Maeda and Karch, 2009, Sutherland and Bickmore, 2009). It has also been suggested that a critical proportion of nearby genes must be active in order to maintain a region of open chromatin (Sproul et al., 2005) and this, too, would favour clustering. Different animal groups alive today may display Hox gene arrangements which are a compromise between the opposing benefits of Hox gene clustering and Hox gene dispersal. In the case of vertebrates, conserved clustering may further be explained by the acquisition of global enhancers located outside the clusters (Duboule, 2007).

\section{Significance of collinearity model 3 : chromatin closing}

Within any cell, the collinearity rule dictates that the active Hox genes are all located in a discreet block; and the inactive genes are confined in a separate discreet block (Fig. 1A). We earlier proposed that the discreet block of repressed genes might be an important feature of a mechanism whereby Pc protein repression coats the genes by spreading along the cluster, moving from one gene to the next (Gaunt, 1991, Gaunt and Singh, 1990). This idea was based upon the observations that Pc protein has homology with the heterochromatin protein HP1 (Paro, 1990), and that heterochromatin itself establishes by a spreading mechanism. More recent results support the idea that Pc repression moves along DNA by spreading (Talbert and Henikoff, 2006). The model proposes that spatial collinearity is required not for establishment of Hox activity, but for subsequent cellular memory of Hox gene expression patterns.

The chromatin closing model has not been supported by subsequent studies in Drosophila. In this species, polycomb repression initiates atPREs and then spreads by a process of looping or hopping to neighbouring regions (Pirrotta and Rastelli, 1994, Talbert and Henikoff, 2006). Multiple PREs have been found in BX-C, including the BxdPRE, the Fab-7PRE and Mcp (Busturia et al., 2001, Ho et al., 2009, Horard et al., 2000, Mihaly et al., 1997). This suggests that initiation and maintenance of polycomb repression need not occur by spread of polycomb proteins across groups of contiguous Hox genes, at least not in Drosophila. Indeed, it is suggested that Hox genes in Drosophila function as independent modules, operating in a parasegment specific manner, and each with its own PRE and boundary elements (Mihaly et al., 1997, Negre and Ruiz, 2007). The situation in vertebrates is less clear since PREs are, with two possible exceptions (Vasanthi et al., 2013, Woo et al., 2010), poorly understood. Until we have data from more species it is difficult to assess whether polycomb spreading might be a reasonable explanation for the ancestral origins of spatial collinearity.

\section{Significance of collinearity model 4: chromatin opening}

As described above, temporal collinearity itself does not necessarily have any function. Spatial collinearity might be the important feature, and temporal collinearity may simply be a consequence of this. However, many researchers view temporal collinearity as more than a trivial consequence of spatial collinearity (Duboule, 1994, Monteiro and Ferrier, 2006, van der Hoeven et al., 1996). They view it instead as a progressive, time-regulated opening of the Hox cluster chromatin within the cells of the posterior growth zone. The opening occurs while cells remain within the growth zone. This chromatin opening enables expression of the Hox genes, and thereby regulates establishment of Hox expression patterns within cells as they are successively added to the growing head-tail axis. Subsequent maintenance of the chromatin changes could then lead on to cellular memory of Hox activity. Importantly, temporal collinearity of Hox gene expression is also shown in vitro by ES cells after addition of retinoic acid (Morey et al., 2007, Simeone et al., 1991). In this case, temporal collinearity cannot simply be explained away by the fact that vertebrate embryos develop in a head-to-tail sequence. The mechanism of temporal collinearity is not known.

As in vertebrates, development of the axis from posterior growth zones also occurs in some annelids, and these animals similarly show temporal collinearity. It has been proposed that this is the ancestral condition which would have been present in Urbilateria (Ferrier and Holland, 2002). However, Duboule considered this unlikely, and suggested that temporal collinearity is more likely to be a secondarily evolved condition, made possible by the presence of the Hox cluster (Duboule, 2007).

The chromatin opening model has itself evolved over the years between 'instructive' and 'restrictive' forms (Tschopp et al., 2009). In instructive form (Duboule, 1994) it proposes that chromatin opening leads directly to the sequential expression of Hox genes in the growth zone. In restrictive form (Tschopp et al., 2009) it proposes that opening may not be directly responsible for timing 
of Hox gene activation but the delay that it imposes on opening of posterior, dominant genes may be important to prevent their premature, accidental expression.

The chromatin opening model, at least in its instructive form, predicts that a Hox gene must lie within the Hox cluster if it is to be activated with a normal boundary of expression. For both mouse and Drosophila, however, Hox/lacZ transgenes randomly integrated in the genome can provide Hox-like patterns of expression provided only that they contain the relevant local enhancer elements (Fig. 4). The enhancers are responding to morphogenetic signalling molecules. In vertebrates, these include retinoic acid, FGF, Gdf11 and $\mathrm{Cdx}$ proteins. We know that Hox/lacZ reporters are not just responding to auto-regulatory cues from endogenous Hox genes, as has been suggested (Gould et al., 1997), because for example, multiple Cdx binding sites within the transgenes (Charite et al., 1998, Gaunt et al., 2004), or increased Cdx dosage (Juan and Ruddle, 2003, Schyr et al., 2012), can drive lacZ expression both earlier and anterior to expression of the endogenous gene. While results for Hox/lacZ transgenes argue against the instructive form of the chromatin opening model they may still be accommodated by the restrictive form. It may, in addition, be important to note that not all Hox genes are found to have local enhancer elements active in lacZ reporters (Tschopp et al., 2012).

In studies upon mouse embryos, Duboule and others have shown that temporal collinearity in gene activation along the Hox clusters is, at least to some extent, accompanied by temporal collinearity in establishment of $\mathrm{Pc} / \mathrm{Trx}$ chromatin changes along the Hox clusters, as predicted by the chromatin opening model (Fig. 6) (Soshnikova and Duboule, 2009). At a gene-by-gene level, however, the sequential opening of chromatin may not correlate in time with Hox gene expression. Thus, when Mazzoni et al., added RA to mouse ES cells, all the anterior Hox genes lost Pc very rapidly, at apparently the same time. Yet, these authors observed that the Hox genes subsequently expressed with temporal collinearity (Mazzoni et al., 2013). Similarly, other authors have noted that chromatin changes in RA-treated ES cells may occur within a Hox gene many days before it is first expressed (Chambeyron and Bickmore, 2004). It does remain possible, however, that ES cells are not an ideal model for growth zones in the primitive streak/tailbud.

Re-arrangements of genes within mouse Hox clusters have produced conflicting evidence in support of the chromatin opening model. Targeting of a Hoxd9/lacZ reporter upstream of Hoxd13 delayed its expression relative to endogenous Hoxd9, and this was in keeping with the proposal that collinearity in expression of Hox genes can be explained by a progressive opening $\left(3^{\prime}\right.$ to $\left.5^{\prime}\right)$ of a repressed chromatin configuration along the Hox cluster (Kondo et al., 1998, van der Hoeven etal., 1996). However, it was subsequently found that a Hoxb1/lacZ transgene targeted upstream of Hoxd13 was not delayed in its expression and, furthermore, this caused premature expression of Hoxd13 (Kmita et al., 2000). Hoxd9/lacZ upstream of Hoxd13also resulted in premature Hoxd13expression, and Hoxb1/lacZtargeted upstream of Hoxd3 resulted in a Hoxd3like pattern of lacZ expression (Kmita et al., 2000). Together, these observations are consistent with a view that Hox gene expression along the head-tail axis is, at least to a large extent, regulated by local enhancers, and that re-assortment of Hox genes may cause them to become miss-regulated by proximity to the enhancers of their new neighbours.

Supporters of the chromatin opening model have pointed out that those species that have retained full spatial collinearity do seem to be the ones whose embryos develop by temporal collinearity at a posterior growth zone; for example, vertebrates and some annelids (Duboule, 2007, Monteiro and Ferrier, 2006). In contrast, species that have lost full spatial collinearity include those that have lost temporal collinearity; for example, Drosophila, nematodes, molluscs and tunicates (Ferrier and Holland, 2002). However, we cannot conclude from this that temporal collinearity requires spatial collinearity. The latter group of animals may lack temporal collinearity simply because they do not develop their axes from a posterior growth zone. For Drosophila, this is known to be the case. Nematodes, molluscs and tunicates develop to a greater or lesser extent in accordance with a programmed cell lineage (mosaic development). In future, it will be important to examine new species in order to test further the so-far unbroken correlation between temporal collinearity and presence of an intact Hox cluster.

Also claimed as support for the chromatin opening model is the finding that the cluster of three paraHox genes, duplicated from the proto-Hox cluster whilst still at the two to four gene stage (Garcia-Fernandez, 2005), is also expressed with both spatial and temporal collinearity (Ferrier and Holland, 2002). Here the most posterior gene $(C d x)$ is expressed earliest in time, and this has been regarded as significant (Ferrier and Minguillon, 2003) because temporal collinearity for paraHox genes cannot simply be explained by development of anterior before posterior tissues at the posterior growth zone.

\section{Temporal collinearity without timed chromatin opening}

An attractive feature of the chromatin opening model is that it provides a clear mechanism whereby Hox genes may become activated with temporal collinearity in the posterior growth zone of the vertebrate embryo. However, the roles of known vertebrate Hox gene activators such as RA, FGF, Gdf11 and Cdx proteins are not considered in this model. It is unspecified whether they mediate the opening process, or else play a permissive role, allowing Hox expression after chromatin is opened. In contrast, the other models for Hox gene regulation assume that the known Hox activators play an instructive role in the establishment of Hox expression boundaries. RA, FGF, Gdf11 and Cdx proteins, acting alone or in combination, are usually proposed to function as graded morphogens which activate Hox genes at different threshold concentrations. A problem here, however, is that morphogen gradients typically provide signalling that is graded over distance, whereas the requirement in the growth zone of the embryo is for signalling that is graded over time (Fig. 5). A progressive rise in the concentrations of Hox activators within the growth zones could produce this effect, but this has not been demonstrated. A possible resolution to this dilemma is provided by studies upon activin, a known morphogen which uses similar cell surface receptors and identical intracellular signals (Smad2/3) to the Hox gene activator Gdf11.

In Xenopus embryos, activin induces a range of mesodermal genes in a concentration-dependent manner. The genes Xbra and goosecoid are activated at low and high activin concentrations, respectively (Gurdon et al., 1994). As shown in Fig. 7A, an activinsoaked bead implanted into an explant of early embryonic cells induces $X b r a$ expression in its immediate vicinity within 25 minutes (Gurdon et al., 1995). After two hours the activin has spread out to produce a much wider domain of Xbra expression. This now 
forms a ring, with the area just around the bead expressing only goosecoid. This pattern reflects the facts that $X b r a$ and goosecoid are activated at different concentrations of activin, and also that goosecoid represses Xbra expression. Importantly, Gurdon and colleagues found that after the bead has been removed for a further two hours the expression patterns do not simply revert to the 25 minute appearance, even though the activin gradient has regressed. Instead, each cell maintains a memory of the highest activin concentration to which it was exposed. Each cell can therefore only progress from expressing activin highly-sensitive genes to lesser-sensitive genes, the so called 'ratchet effect'.

The ratchet effect is caused by the internalization of activin bound receptors into vesicles within the cell cytoplasm (Jullien and Gurdon, 2005) (Fig. 7B). Activin bound at the cell surface is susceptible to degradation but that within vesicles is not. Morphogen activity can therefore accumulate with time and continue to activate ever-increasing amounts of the Smad2/3 transcription factors for gene activation. Once the cells have ceased to require morphogen instruction the internalized activin and receptors can become subject to degradation and recycling. The ratchet effect means that morphogen can affect cells differently not only according to position (along a morphogen gradient) but also according to time of their exposure. Although activin is the best studied example, there is evidence that other morphogens may also operate according to both distance and time (Dessaud et al., 2007, Harfe et al., 2004). Morphogen concentrations might therefore become established as 'gradients-over-distance' and/or 'gradients-over-time'.

Gdf11 is a known regulator of more posteriorly expressed Hox genes in vertebrates. It affects Hox expression boundaries in a dose-dependent way. This is seen from both gain- and loss-offunction studies (Liu, 2006, McPherron et al., 1999). For at least one gene, Hoxd11, Gdf11 operates by smad2/3 signalling to a cis enhancer sequence (Gaunt et al., 2013). As expected, Gdf11 is expressed in the region of the primitive streak at the time that new Hox patterns are being generated (McPherron et al., 1999).
There is no direct evidence that different Hox genes are activated at different threshold concentrations of Gdf11, but this conclusion is suggested by the finding that Gdf11 knockout heterozygotes show a level of homeotic shift that is intermediate between that of wild-type and homozygotes (McPherron et al., 1999).

It is tempting to speculate that Gdf11 might be a morphogen for serial activation of posterior Hox genes, and that this might operate by a ratchet mechanism within cells of the growth zones. FGF may act as a morphogen regulating more anterior Hox genes (Bel-Vialar et al., 2002, Partanen et al., 1998), and FGF signalling might also be prolonged by internalization of bound receptors (Haugsten et al., 2005). In future work, Gdf11 and FGF may be tested to see if, like activin, their effective concentrations increase over time by accumulation of bound receptors in endosomes. Some refinement of Hox expression boundaries is known to occur within cells after they have moved from the growth zones (Forlani et al., 2003), and this might be due to morphogens operating as gradients-over-distance.

\section{Conclusions}

We would like to understand why the Hox cluster was established with spatial collinearity. We would also like to understand whether the ancestral constraints are conserved to maintain collinearity in living descendants, or whether different constraints are now operating. Experimental analyses have been made mainly upon Drosophila and mice. We must look for features which appear to be conserved in order to gain possible insight into the ancestral condition, and it may be difficult to decide whether constraints that operate now are the same as those which operated ancestrally.

Published proposals to explain spatial collinearity, which invoke enhancer sharing, chromatin closing or chromatin opening, are either problematic or can offer only partial explanations. In an alternative proposal it is suggested here that collinearity evolved principally to maximise physical segregation, and thereby minimise incidence of boundaries, between active and inactive genes within
A

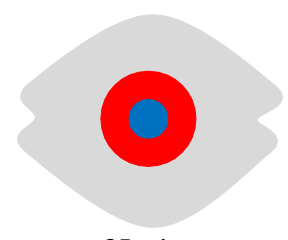

25 mins

activin bead

B

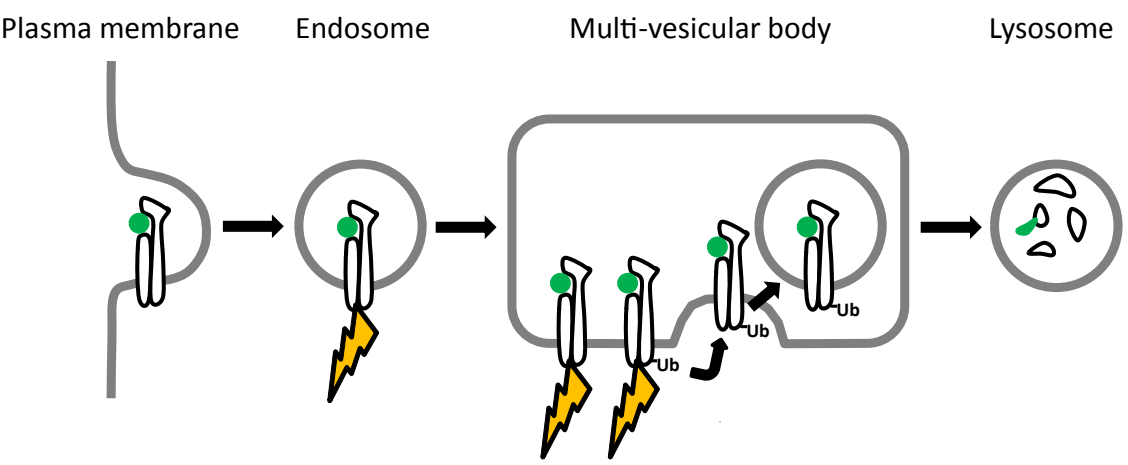

Fig 7. The ratchet effect of activin upon $\mathrm{Xbra}$ and goosecoid expression. (A) An activin bead (b/ue) is sandwiched between two Xenopus animal caps (grey). After 25 minutes Xbra (red) is induced in surrounding cells. After 2 hours the activin has spread by diffusion to induce more distant Xbra, and activin levels around the bead are now high enough to induce goosecoid (yellow). Goosecoid inhibits Xbra causing its loss around the bead. Two hours after removal of the bead activin levels have declined but the Xbra and goosecoid expression patterns are maintained by the ratchet effect (Gurdon et al., 1995). (B) Activin (green) binds in a complex with type 1 and type 2 receptors. This activates smad2/3 mainly while it is in endosomes and the outer membrane of multi-vesicular bodies (lightning bolt). Subsequent ubiquitination inactivates the complex by signalling entry to an internal vesicle of the multi-vesicular body and thence a lysosome (Jullien and Gurdon, 2005). Ub, ubiquitin. 
the Hox cluster. This may minimise erroneous transfer of transcriptional activity, or inactivity, between adjacent Hox genes. The various models discussed are not necessarily mutually exclusive. For example, spatial collinearity may have been established and maintained ancestrally in accordance with the gene segregation hypothesis, but collinearity in vertebrates may then have been utilized secondarily in accordance with a chromatin opening mechanism.

\section{Acknowledgements}

Ithank MichaelAkam and RobAsher for the provision of laboratory space.

\section{References}

AKAM, M., DAWSON, I. and TEAR, G. (1988). Homeotic Genes and the Control of Segment Diversity. Development Supp. 104: 123-133.

AKASAKA, T., VAN LOHUIZEN, M., VAN DER LUGT, N., MIZUTANI-KOSEKI, Y., KANNO, M., TANIGUCHI, M., VIDAL, M., ALKEMA, M., BERNS, A. and KOSEKI, H. (2001). Mice doubly deficient for the Polycomb Group genes Mel18 and Bmi1 reveal synergy and requirement for maintenance but not initiation of Hox gene expression. Development 128: 1587-1597.

ANDREY, G., MONTAVON, T., MASCREZ, B., GONZALEZ, F., NOORDERMEER, D., LELEU, M., TRONO, D., SPITZ, F. and DUBOULE, D. (2013). A switch between topological domains underlies HoxD genes collinearity in mouse limbs. Science 340: 1234167.

AVRAMOVA, Z. (2009). Evolution and pleiotropy of TRITHORAX function in Arabidopsis. Int J Dev Biol 53: 371-381.

BALAVOINE, G., DE ROSA, R. and ADOUTTE, A. (2002). Hox clusters and bilaterian phylogeny. Mol Phylogenet Evol 24: 366-373.

BANTIGNIES, F. and CAVALLI, G. (2011). Polycomb group proteins: repression in 3D. Trends Genet 27: 454-464.

BARGES, S., MIHALY, J., GALLONI, M., HAGSTROM, K., MULLER, M., SHANOWER, G., SCHEDL, P., GYURKOVICS, H. and KARCH, F. (2000). The Fab-8 boundary defines the distal limit of the bithorax complex iab-7 domain and insulates iab-7 from initiation elements and a PRE in the adjacent iab-8 domain. Development 127: $779-790$

BARNETT, A.A. and THOMAS, R.H. (2013). Posterior Hox gene reduction in an arthropod: Ultrabithorax and Abdominal-B are expressed in a single segment in the mite Archegozetes longisetosus. Evodevo 4: 23.

BEL-VIALAR, S., ITASAKI, N. and KRUMLAUF, R. (2002). Initiating Hox gene expression: in the early chick neural tube differential sensitivity to FGF and RA signaling subdivides the HoxB genes in two distinct groups. Development 129: 5103-5115.

BERNSTEIN, B.E., MIKKELSEN, T.S., XIE, X., KAMAL, M., HUEBERT, D.J., CUFF, J., FRY, B., MEISSNER, A., WERNIG, M., PLATH, K. et al., (2006). A bivalent chromatin structure marks key developmental genes in embryonic stem cells. Cell 125: 315-326.

BONCINELLI, E., SOMMA, R., ACAMPORA, D., PANNESE, M., D'ESPOSITO, M., FAIELLA, A. and SIMEONE, A. (1988). Organization of human homeobox genes. Hum Reprod 3: 880-886.

BOWMAN, S.K., DEATON, A.M., DOMINGUES, H., WANG, P.I., SADREYEV, R.I., KINGSTON, R.E. and BENDER, W. (2014). H3K27 modifications define segmental regulatory domains in the Drosophila bithorax complex. Elife 3: e02833.

BUSTURIA, A., LLOYD, A., BEJARANO, F., ZAVORTINK, M., XIN, H. and SAKONJU, S. (2001). The MCP silencer of the Drosophila Abd-B gene requires both Pleiohomeotic and GAGA factor for the maintenance of repression. Development 128: 2163-2173.

CASA, V. and GABELLINI, D. (2012). A repetitive elements perspective in Polycomb epigenetics. Front Genet 3: 199

CELNIKER, S.E., SHARMA, S., KEELAN, D.J. and LEWIS, E.B. (1990). The molecular genetics of the bithorax complex of Drosophila: cis-regulation in the Abdominal-B domain. EMBO J 9: 4277-4286.

CHAMBEYRON, S. and BICKMORE, W.A. (2004). Chromatin decondensation and nuclear reorganization of the HoxB locus upon induction of transcription. Genes Dev 18: 1119-1130.

CHARITE, J., DE GRAAFF, W., CONSTEN, D., REIJNEN, M.J., KORVING, J. and
DESCHAMPS, J. (1998). Transducing positional information to the Hox genes: critical interaction of $\mathrm{cdx}$ gene products with position-sensitive regulatory elements. Development 125: 4349-4358.

DE ROBERTIS, E.M. (2008). Evo-Devo: Variations on ancestral themes. Cell 132: 185-195.

DESSAUD, E., YANG, L.L., HILL, K., COX, B., ULLOA, F., RIBEIRO, A., MYNETT, A., NOVITCH, B.G. and BRISCOE, J. (2007). Interpretation of the sonic hedgehog morphogen gradient by a temporal adaptation mechanism. Nature 450: 717-720.

DUBOULE, D. (1994). Temporal colinearity and the phylotypic progression: a basis for the stability of a vertebrate Bauplan and the evolution of morphologies through heterochrony. Development Supp. 135-142.

DUBOULE, D. (2007). The rise and fall of Hox gene clusters. Development 134 2549-2560.

DUBOULE, D. and DOLLE, P. (1989). The structural and functional organization of the murine HOX gene family resembles that of Drosophila homeotic genes. EMBO J 8: 1497-1505

DUBOULE, D. and MORATA, G. (1994). Colinearity and functional hierarchy among genes of the homeotic complexes. Trends Genet 10: 358-364.

FERRIER, D.E. and HOLLAND, P.W. (2002). Ciona intestinalis ParaHox genes: evolution of Hox/ParaHox cluster integrity, developmental mode, and temporal colinearity. Mol Phylogenet Evol 24: 412-417.

FERRIER, D.E. and MINGUILLON, C. (2003). Evolution of the Hox/ParaHox gene clusters. Int J Dev Biol 47: 605-611.

FORLANI, S., LAWSON, K.A. and DESCHAMPS, J. (2003). Acquisition of Hox codes during gastrulation and axial elongation in the mouse embryo. Development 130: 3807-3819.

FROBIUS, A.C., MATUS, D.Q. and SEAVER, E.C. (2008). Genomic organization and expression demonstrate spatial and temporal Hox gene colinearity in the lophotrochozoan Capitella sp. I. PLoS One 3: e4004.

GARCIA-FERNANDEZ, J. (2005). The genesis and evolution of homeobox gene clusters. Nature Rev. Genet. 6: 881-892.

GARCIA-FERNANDEZ, J. and HOLLAND, P.W. (1994). Archetypal organization of the amphioxus Hox gene cluster. Nature 370: 563-566.

GAUNT, S.J. (1991). Expression patterns of mouse Hox genes: clues to an understanding of developmental and evolutionary strategies. Bioessays 13: 505-513.

GAUNT, S.J., COCKLEY, A. and DRAGE, D. (2004). Additional enhancer copies, with intact $c d x$ binding sites, anteriorize Hoxa-7/lacZ expression in mouse embryos: evidence in keeping with an instructional cdx gradient. Int J Dev Biol 48: 613-622.

GAUNT, S.J., GEORGE, M. and PAUL, Y.L. (2013). Direct activation of a mouse Hoxd11 axial expression enhancer by Gdf11/Smad signalling. DevBio/383:52-60.

GAUNT, S.J., SHARPE, P.T. and DUBOULE, D. (1988). Spatially Restricted Domains of Homeo-Gene Transcripts in Mouse Embryos - Relation to a Segmented Body Plan. Development Supp. 104: 169-179.

GAUNT, S.J. and SINGH, P.B. (1990). Homeogene expression patterns and chromosomal imprinting. Trends Genet 6: 208-212.

GEHRING, W.J., KLOTER, U. and SUGA, H. (2009). Evolution of the Hox gene complex from an evolutionary ground state. Curr Top Dev Biol 88: 35-61.

GOULD, A., MORRISON, A., SPROAT, G., WHITE, R.A. and KRUMLAUF, R. (1997). Positive cross-regulation and enhancer sharing: two mechanisms for specifying overlapping Hox expression patterns. Genes Dev 11: 900-913.

GRAHAM, A., PAPALOPULU, N. and KRUMLAUF, R. (1989). The murine and Drosophila homeobox gene complexes have common features of organization and expression. Cell 57: 367-378.

GURDON, J.B., HARGER, P., MITCHELL, A. and LEMAIRE, P. (1994). Activin signalling and response to a morphogen gradient. Nature 371: 487-492.

GURDON, J.B., MITCHELL, A. and MAHONY, D. (1995). Direct and continuous assessment by cells of their position in a morphogen gradient. Nature 376: 520-521.

HARDING, K., WEDEEN, C., MCGINNIS, W. and LEVINE, M. (1985). Spatially regulated expression of homeotic genes in Drosophila. Science 229: 1236-1242.

HARFE, B.D., SCHERZ, P.J., NISSIM, S., TIAN, H., MCMAHON, A.P. and TABIN, C.J. (2004). Evidence for an expansion-based temporal Shh gradient in specifying vertebrate digit identities. Cell 118: 517-528.

HAUGSTEN, E.M., SORENSEN, V., BRECH, A., OLSNES, S. and WESCHE, J. (2005) Different intracellular trafficking of FGF1 endocytosed by the four homologous 
FGF receptors. J Cell Sci 118: 3869-3881.

HENNIG, L. and DERKACHEVA, M. (2009). Diversity of Polycomb group complexes in plants: same rules, different players? Trends Genet 25: 414-423.

HO, M.C.W, SCHILLER, B.J., GOETZ, S.E. and DREWELL, R.A. (2009). Non-genic transcription at the Drosophila bithorax complex - functional activity of the dark matter of the genome. Int J Dev Biol 53: 459-468.

HORARD, B., TATOUT, C., POUX, S. and PIRROTTA, V. (2000). Structure of a polycomb response element and in vitro binding of polycomb group complexes containing GAGA factor. Mol Cell Biol 20: 3187-3197.

HUGHES, C.L. and KAUFMAN, T.C. (2002). Exploring the myriapod body plan: expression patterns of the ten Hox genes in a centipede. Development 129: 1225-1238.

IZPISUA-BELMONTE, J.C., FALKENSTEIN, H., DOLLE, P., RENUCCI, A. and DUBOULE, D. (1991). Murine genes related to the Drosophila AbdB homeotic genes are sequentially expressed during development of the posterior part of the body. EMBO J 10: 2279-2289.

JUAN, A.H. and RUDDLE, F.H. (2003). Enhancer timing of Hox gene expression: deletion of the endogenous Hoxc8 early enhancer. Development 130: 4823-4834.

JULLIEN, J. and GURDON, J. (2005). Morphogen gradient interpretation by a regulated trafficking step during ligand-receptor transduction. Genes Dev 19: 2682-2694.

KAUFMAN, T.C., LEWIS, R. and WAKIMOTO, B. (1980). Cytogenetic Analysis of Chromosome 3 in DROSOPHILA MELANOGASTER: The Homoeotic Gene Complex in Polytene Chromosome Interval 84a-B. Genetics 94: 115-133.

KMITA, M., VAN DER HOEVEN, F., ZAKANY, J., KRUMLAUF, R. and DUBOULE, D. (2000). Mechanisms of Hox gene colinearity: transposition of the anterior Hoxb1 gene into the posterior HoxD complex. Genes Dev 14: 198-211.

KONDO, T., ZAKANY, J. and DUBOULE, D. (1998). Control of colinearity in AbdB genes of the mouse HoxD complex. Mol Cell 1: 289-300.

KWAN, C.T., TSANG, S.L., KRUMLAUF, R. and SHAM, M.H. (2001). Regulatory analysis of the mouse Hoxb3 gene: multiple elements work in concert to direct temporal and spatial patterns of expression. Dev Biol 232: 176-190.

LANZUOLO, C., ROURE, V., DEKKER, J., BANTIGNIES, F. and ORLANDO, V. (2007). Polycomb response elements mediate the formation of chromosome higher-order structures in the bithorax complex. Nat Cell Biol 9: 1167-1174.

LEWIS, E.B. (1978). A gene complex controlling segmentation in Drosophila. Nature 276: 565-570.

LEWIS, E.B. (1985). Regulation of the genes of the bithorax complex in Drosophila. Cold Spring Harb Symp Quant Biol 50: 155-164.

LEWIS, E.B. (1998). The bithorax complex: the first fifty years. Int J Dev Bio/42: 403-415.

LIU, J.P. (2006). The function of growth/differentiation factor 11 (Gdf11) in rostrocaudal patterning of the developing spinal cord. Development 133: 2865-2874.

MAEDA, R.K. and KARCH, F. (2006). The ABC of the BX-C: the bithorax complex explained. Development 133: 1413-1422.

MAEDA, R.K. and KARCH, F. (2009). The bithorax complex of Drosophila an exceptional Hox cluster. Curr Top Dev Biol 88: 1-33.

MAEDA, R.K. and KARCH, F. (2015). The open for business model of the bithorax complex in Drosophila. Chromosoma 124: 293-307.

MAINGUY, G., KOSTER, J., WOLTERING, J., JANSEN, H. and DURSTON, A. (2007). Extensive polycistronism and antisense transcription in the mammalian Hox clusters. PLoS One 2: e356.

MARTINEZ-ARIAS, A. and LAWRENCE, P.A. (1985). Parasegments and compartments in the Drosophila embryo. Nature 313: 639-642.

MAZZONI, E.O., MAHONY, S., PELJTO, M., PATEL, T., THORNTON, S.R., MCCUINE, S., REEDER, C., BOYER, L.A., YOUNG, R.A., GIFFORD, D.K. et al., (2013). Saltatory remodeling of Hox chromatin in response to rostrocaudal patterning signals. Nat Neurosci 16: 1191-1198.

MCPHERRON, A.C., LAWLER, A.M. and LEE, S.J. (1999). Regulation of anterior/ posterior patterning of the axial skeleton by growth/differentiation factor 11. Nat Genet 22: 260-264.

MIHALY, J., HOGGA, I., GAUSZ, J., GYURKOVICS, H. and KARCH, F. (1997). In situ dissection of the Fab-7 region of the bithorax complex into a chromatin domain boundary and a Polycomb-response element. Development 124: 1809-1820.

MONTEIRO, A.S. and FERRIER, D.E. (2006). Hox genes are not always Colinear. Int J Biol Sci 2: 95-103.

MOREY, C., DA SILVA, N.R., PERRY, P. and BICKMORE, W.A. (2007). Nuclear reor- ganisation and chromatin decondensation are conserved, but distinct, mechanisms linked to Hox gene activation. Development 134: 909-919.

NARENDRA, V., ROCHA, P.P., AN, D., RAVIRAM, R., SKOK, J.A., MAZZONI, E.O. and REINBERG, D. (2015). Transcription. CTCF establishes discrete functional chromatin domains at the Hox clusters during differentiation. Science 347: 1017-1021.

NEGRE, B. and RUIZ, A. (2007). HOM-C evolution in Drosophila: is there a need for Hox gene clustering? Trends Genet 23: 55-59.

NOORDERMEER, D., LELEU, M., SPLINTER, E., ROUGEMONT, J., DE LAAT, W. and DUBOULE, D. (2011). The dynamic architecture of Hox gene clusters. Science 334: 222-225.

PARO, R. (1990). Imprinting a determined state into the chromatin of Drosophila. Trends Genet 6: 416-421.

PARTANEN, J., SCHWARTZ, L. and ROSSANT, J. (1998). Opposite phenotypes of hypomorphic and $\mathrm{Y} 766$ phosphorylation site mutations reveal a function for Fgfr1 in anteroposterior patterning of mouse embryos. Genes Dev 12: 2332-2344.

PASCUAL-ANAYA, J., ADACHI, N., ALVAREZ, S., KURATANI, S., D'ANIELLO, S. and GARCIA-FERNANDEZ, J. (2012). Broken colinearity of the amphioxus Hox cluster. Evodevo 3: 28.

PIRROTTA, V. and RASTELLI, L. (1994). White gene expression, repressive chromatin domains and homeotic gene regulation in Drosophila. Bioessays 16: 549-556.

SANCHEZ-HERRERO, E. and AKAM, M. (1989). Spatially ordered transcription of regulatory DNAin the bithorax complex of Drosophila. Development 107:321-329.

SANCHEZ-HERRERO, E., VERNOS, I., MARCO, R. and MORATA, G. (1985). Genetic organization of Drosophila bithorax complex. Nature 313: 108-113.

SCHNEUWLY, S., KUROIWA, A. and GEHRING, W.J. (1987). Molecular analysis of the dominant homeotic Antennapedia phenotype. EMBO J 6: 201-206.

SCHUETTENGRUBER, B. and CAVALLI, G. (2009). Recruitment of polycomb group complexes and their role in the dynamic regulation of cell fate choice. Development 136: 3531-3542.

SCHUETTENGRUBER, B., CHOURROUT, D., VERVOORT, M., LEBLANC, B. and CAVALLI, G. (2007). Genome regulation by polycomb and trithorax proteins. Cell 128: 735-745.

SChUetTengruber, B., GANAPATHI, M., LeBlanc, B., PORTOSO, M., JASCHEK, R., TOLHUIS, B., VAN LOHUIZEN, M., TANAY, A. and CAVALLI, G. (2009). Functional anatomy of polycomb and trithorax chromatin landscapes in Drosophila embryos. PLoS Biol 7: e13.

SCHWARTZ, Y.B. and PIRROTTA, V. (2007). Polycomb silencing mechanisms and the management of genomic programmes. Nature Rev. Genet. 8: 9-22.

SCHYR, R.B., SHABTAI, Y., SHASHIKANT, C.S. and FAINSOD, A. (2012). Cdx1 is essential for the initiation of $\mathrm{HoxC} 8$ expression during early embryogenesis. FASEB J 26: 2674-2684.

SEO, H.C., EDVARDSEN, R.B., MAELAND, A.D., BJORDAL, M., JENSEN, M.F., HANSEN, A., FLAAT, M., WEISSENBACH, J., LEHRACH, H., WINCKER, P. et al., (2004). Hox cluster disintegration with persistent anteroposterior order of expression in Oikopleura dioica. Nature 431: 67-71.

SHA, K. and BOYER, L.A. (2009). The chromatin signature of pluripotent cells. StemBook, ed. The Stem Cell Research community, Stembook. doi/10.3824/ stembook.1.45.1, http://www.stembook.org/node/585.

SHARPE, J., NONCHEV, S., GOULD, A., WHITING, J. and KRUMLAUF, R. (1998). Selectivity, sharing and competitive interactions in the regulation of Hoxb genes. EMBO J 17: 1788-1798.

SHIGA, Y., SAGAWA, K., TAKAI, R., SAKAGUCHI, H., YAMAGATA, H. and HAYASHI, S. (2006). Transcriptional readthrough of Hox genes Ubx and Antp and their divergent post-transcriptional control during crustacean evolution. Evolution \& Development 8: 407-414.

SIMEONE, A., ACAMPORA, D., NIGRO, V., FAIELLA, A., D'ESPOSITO, M., STORNAIUOLO, A., MAVILIO, F. and BONCINELLI, E. (1991). Differential regulation by retinoic acid of the homeobox genes of the four HOX loci in human embryonal carcinoma cells. Mech Dev 33: 215-227.

SIMEONE, A., PANNESE, M., ACAMPORA, D., D'ESPOSITO, M. and BONCINELLI, E. (1988). At least three human homeoboxes on chromosome 12 belong to the same transcription unit. Nucleic Acids Res 16: 5379-5390.

SIMON, J.A. and KINGSTON, R.E. (2013). Occupying chromatin: Polycomb mechanisms for getting to genomic targets, stopping transcriptional traffic, and staying put. Mol Cell 49: 808-824. 
SOSHNIKOVA, N. and DUBOULE, D. (2009). Epigenetic temporal control of mouse Hox genes in vivo. Science 324: 1320-1323.

SPITZ, F., GONZALEZ, F. and DUBOULE, D. (2003). A global control region defines a chromosomal regulatory landscape containing the HoxD cluster. Cell113:405-417.

SPITZ, F., GONZALEZ, F., PEICHEL, C., VOGT, T.F., DUBOULE, D. and ZAKANY, J. (2001). Large scale transgenic and cluster deletion analysis of the HoxD complex separate an ancestral regulatory module from evolutionary innovations. Genes Dev 15: 2209-2214

SPITZ, F., HERKENNE, C., MORRIS, M.A. and DUBOULE, D. (2005). Inversioninduced disruption of the Hoxd cluster leads to the partition of regulatory landscapes. Nat Genet 37: 889-893.

SPROUL, D., GILBERT, N. and BICKMORE, W.A. (2005). The role of chromatin structure in regulating the expression of clustered genes. Nature Rev. Genet. 6: 775-781.

STEFFEN, P.A. and RINGROSE, L. (2014). What are memories made of? How Polycomb and Trithorax proteins mediate epigenetic memory. Nat Rev Mol Cell Biol 15: 340-356.

STRUHL, G. and WHITE, R.A. (1985). Regulation of the Ultrabithorax gene of Drosophila by other bithorax complex genes. Cell 43: 507-519.

SUTHERLAND, H. and BICKMORE, W.A. (2009). Transcription factories: gene expression in unions? Nature Rev. Genet. 10: 457-466.

SWEETMAN, D., WAGSTAFF, L., COOPER, O., WEIJER, C. and MUNSTERBERG, A. (2008). The migration of paraxial and lateral plate mesoderm cells emerging from the late primitive streak is controlled by different Wnt signals. BMC Dev Biol 8: 63.

TALBERT, P.B. and HENIKOFF, S. (2006). Spreading of silent chromatin: inaction at a distance. Nature Rev. Genet. 7: 793-803.

TARAILO-GRAOVAC, M. and CHEN, N. (2013). Gene clustering in eukaryotes. In: eLS. John Wiley \& Sons Ltd: Chichester.
TSCHOPP, P., CHRISTEN, A.J. and DUBOULE, D. (2012). Bimodal control of Hoxd gene transcription in the spinal cord defines two regulatory subclusters. Development 139: 929-939.

TSCHOPP, P., TARCHINI, B., SPITZ, F., ZAKANY, J. and DUBOULE, D. (2009). Uncoupling time and space in the collinear regulation of Hox genes. PLOS Genet 5: e1000398.

VAN DER HOEVEN, F., ZAKANY, J. and DUBOULE, D. (1996). Gene transpositions in the HoxD complex reveal a hierarchy of regulatory controls. Cell85: 1025-1035.

VASANTHI, D., ANANT, M., SRIVASTAVA, S. and MISHRA, R.K. (2010). A functionally conserved boundary element from the mouse HoxD locus requires GAGA factor in Drosophila. Development 137: 4239-4247.

VASANTHI, D., NAGABHUSHAN, A., MATHARU, N.K. and MISHRA, R.K. (2013). A functionally conserved Polycomb response element from mouse HoxD complex responds to heterochromatin factors. Sci Rep 3: 3011.

WANG, K.C., HELMS, J.A. and CHANG, H.Y. (2009). Regeneration, repair and remembering identity: the three Rs of Hox gene expression. Trends Cell Biol 19:268-275.

WILSON, V., OLIVERA-MARTINEZ, I. and STOREY, K.G. (2009). Stem cells, signals and vertebrate body axis extension. Development 136: 1591-1604.

WOO, C.J., KHARCHENCO, P.V., DAHERON, L., PARK, P.J. and KINGSTON, R.E. (2010). A region of the human HoxD cluster that confers Polycomb-group responsiveness. Cell 140:99-110.

YU, B.D., HANSON, R.D., HESS, J.L., HORNING, S.E. and KORSMEYER, S.J. (1998). MLL, a mammalian trithorax-group gene, functions as a transcriptiona maintenance factor in morphogenesis. Proc Natl Acad Sci USA 95: 10632-10636.

ZAKANY, J., GERARD, M., FAVIER, B. and DUBOULE, D. (1997). Deletion of a HoxD enhancer induces transcriptional heterochrony leading to transposition of the sacrum. EMBO J 16: 4393-4402. 


\section{Further Related Reading, published previously in the Int. J. Dev. Biol.}

Non-genic transcription at the Drosophila bithorax complex - functional activity of the dark matter of the genome Margaret C.W. Ho, Benjamin J. Schiller, Sara E. Goetz and Robert A. Drewell

Int. J. Dev. Biol. (2009) 53: 459-468

http://dx.doi.org/10.1387/ijdb.082647mh

\section{Evolution and pleiotropy of TRITHORAX function in Arabidopsis}

Zoya Avramova

Int. J. Dev. Biol. (2009) 53: 371-381

http://dx.doi.org/10.1387/ijdb.082664za

Additional enhancer copies, with intact cdx binding sites, anteriorize Hoxa-7/lacZ expression in mouse embryos: evidence in keeping with an instructional cdx gradient Stephen J. Gaunt, Adam Cockley and Deborah Drage

Int. J. Dev. Biol. (2004) 48: 613-622

http://dx.doi.org/10.1387/ijdb.041829sg

\section{Evolution of the Hox/ParaHox gene clusters}

David E K Ferrier and Carolina Minguillón

Int. J. Dev. Biol. (2003) 47: 605-611

http://dx.doi.org/10.1387/ijdb.14756336

The bithorax complex: the first fifty years

E B Lewis

Int. J. Dev. Biol. (1998) 42: 403-415

http://dx.doi.org/10.1387/ijdb.9654025

5 yr ISI Impact Factor $(2013)=2.879$

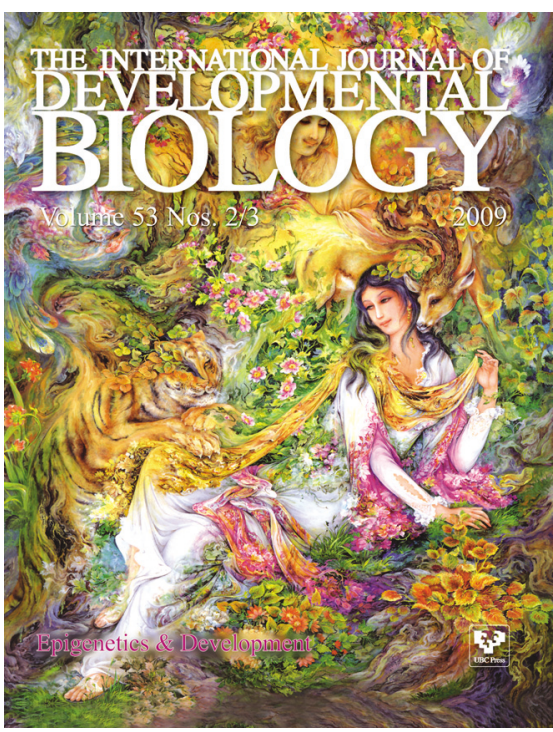

Volume 47 Nos. $7 / 8$

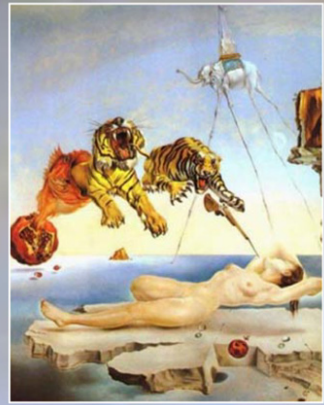

Evolution \& Development
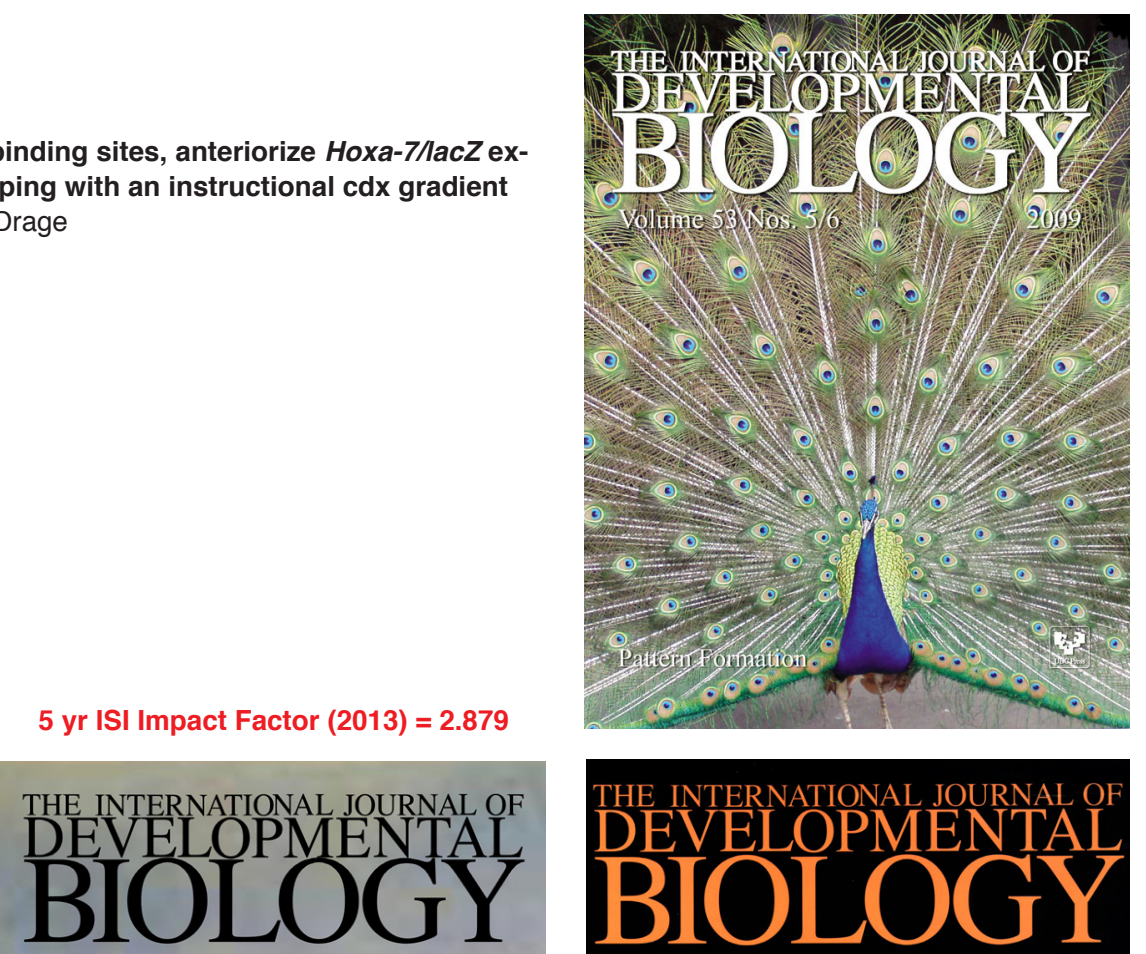

Special Issue

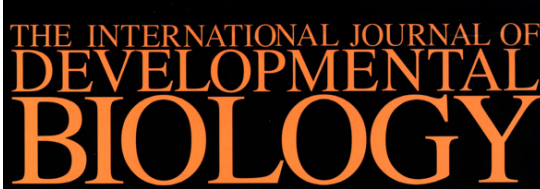

Volume 42 No. 3

Special issue

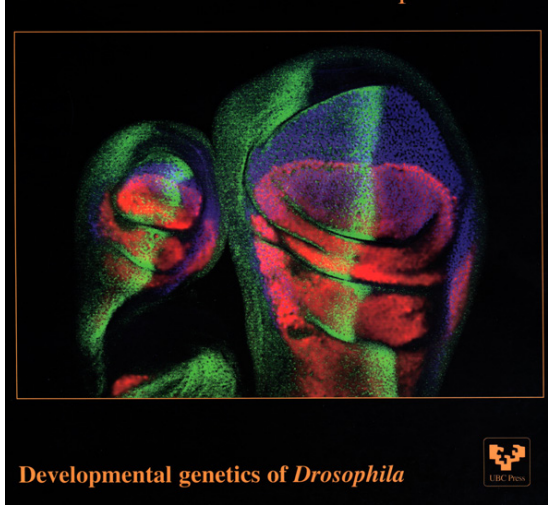

